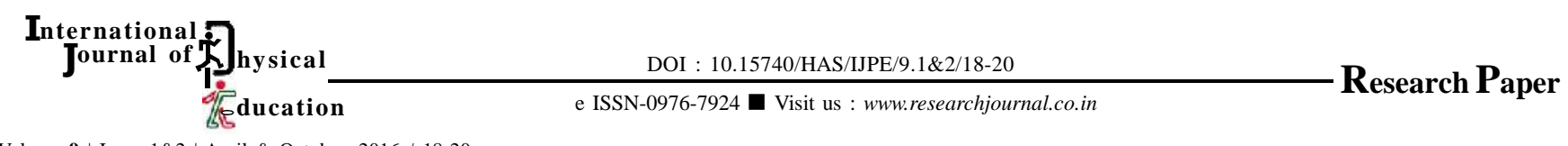

Volume 9 | Issue $1 \& 2$ | April \& October, 2016 | 18-20

\title{
Effect of Bhramari Pranayama on the state of anxiety on sedentary male from Gwalior
}

DIWAKAR PAL

Received : 12.08.2016; Revised : 09.09.2016; Accepted : 23.09.2016

Author for correspondence

DIWAKAR PAL

Department of Physical Education,

Institute of Professsional Studies,

GWALIOR (M.P.) INDIA

\section{-ABSTRACT}

The objective of this study was to determine the effects of Bhramari Pranayama on State Anxiety on sedentary male. The subjects for this study were selected from the Gwalior. A total of 40 sedentary male subjects were selected and used as one experimental group (20) and other control group (20). Bhramari Pranayama was considered the independent variable and state Anxiety was considered the dependent variable. Anxiety was measured with STAS Anxiety Questionnaire. Training was given up to two months. 3 times in week; each session scheduled for 40 minutes. The pre test post test randomize group design was used for this study. Tests were administered before the training programme and after the completion of the treatment again test were administered. ANCOVA was used to locate significance effects of Bhramari Pranayama on Anxiety in school going children.At 0.05 levels of significance. In relation to Anxiety, effect of Bhramari Pranayama was found significant.

- KEY WORDS : Bhramari Pranayama, State anxiety

- HOW TO CITE THIS PAPER : Pal, Diwakar (2016). Effect of Bhramari Pranayama on the state of anxiety on sedentary male from Gwalior. Internat. J. Phy. Edu., 9 (1\&2) : 18-20, DOI : 10.15740/HAS/ IJPE/9.1\&2/18-20. 